\title{
Simultaneous Biosorption of Arsenic and Cadmium onto Chemically Modified Chlorella vulgaris and Spirulina platensis
}

\author{
Wenlong Lu ${ }^{1,2}$, Yifeng $X u^{1,2}$, Chuanzhou Liang ${ }^{1,2}$, Baba Imoro Musah ${ }^{1,2}$ and Lai Peng $^{1,2, *}$ \\ 1 Hubei Key Laboratory of Mineral Resources Processing and Environment, Wuhan University of Technology, \\ Luoshi Road 122, Wuhan 430070, China; 293716@whut.edu.cn (W.L.); yifeng.xu@whut.edu.cn (Y.X.); \\ liangchuanzhou@whut.edu.cn (C.L.); babamusah94@whut.edu.cn (B.I.M.) \\ 2 School of Resources and Environmental Engineering, Wuhan University of Technology, Luoshi Road 122, \\ Wuhan 430070, China \\ * Correspondence: lai.peng@whut.edu.cn; Tel.: +86-138-7156-1850
}

check for updates

Citation: Lu, W.; Xu, Y.; Liang, C.; Musah, B.I.; Peng, L. Simultaneous Biosorption of Arsenic and Cadmium onto Chemically Modified Chlorella vulgaris and Spirulina platensis. Water 2021, 13, 2498. https://doi.org/ $10.3390 /$ w13182498

Academic Editor: Laura Bulgariu

Received: 18 August 2021

Accepted: 8 September 2021

Published: 11 September 2021

Publisher's Note: MDPI stays neutral with regard to jurisdictional claims in published maps and institutional affiliations.

Copyright: (c) 2021 by the authors. Licensee MDPI, Basel, Switzerland. This article is an open access article distributed under the terms and conditions of the Creative Commons Attribution (CC BY) license (https:// creativecommons.org/licenses/by/ $4.0 /)$.

\begin{abstract}
The biosorption behaviour of arsenic(V) and cadmium(II) ions by unmodified and five types of chemically modified Chlorella vulgaris and Spirulina platensis was investigated. The biosorption rates of $\mathrm{As}(\mathrm{V})$ and $\mathrm{Cd}(\mathrm{II})$ in binary metal solutions were lower than those in sole metal systems, which exhibited a competition between $\mathrm{As}(\mathrm{V})$ and $\mathrm{Cd}(\mathrm{II})$ ions to occupy the active sites of the adsorbent. Among the five chemical reagents, $\mathrm{NaCl}$ and $\mathrm{ZnCl}_{2}$ were the most suitable modifiers for improving the biosorption performance of $C$. vulgaris and S. platensis, respectively. The maximum biosorption capacities of $\mathrm{As}(\mathrm{V})$ and $\mathrm{Cd}(\mathrm{II})$ were: (a) 20.9 and $1.2 \mathrm{mg} / \mathrm{g}$, respectively, for C. vulgaris modified with $\mathrm{NaCl}$; (b) 24.8 and $29.4 \mathrm{mg} / \mathrm{g}$, respectively, for $S$. platensis modified with $\mathrm{ZnCl}_{2}$, which were much higher than those using other chemically modifying methods. The pseudo-second-order kinetic model fitted well with all the biosorption processes. The SEM analysis revealed that the modification changed the surface morphologies and enhanced the porosity of the algae biomass. The FTIR analysis established the presence of diverse groups of compounds that were largely hydroxyl, carboxylate, amino, and amide groups on the adsorbents that contributed significantly to the upregulated biosorption. This work showed the potential application of chemically modified $C$. vulgaris and S. platensis biomasses to effectively remove both from water.
\end{abstract}

Keywords: arsenic; cadmium; simultaneous biosorption; algae; chemical modification

\section{Introduction}

Arsenic(V) and cadmium(II) are trace elements with bio-accumulative properties that pose a wide range of severe risks to human health and environmental sustainability, due to their non-degradability and persistence [1]. As(V) and Cd(II) are mostly constituents of wastewater generated by metal smelting, pesticide insecticide production, and mining activities [2-4]. Due to the indiscriminate discharge of wastewater in the environment, $\mathrm{As}(\mathrm{V})$ and $\mathrm{Cd}(\mathrm{II})$ can easily percolate into the soil, water bodies, and plants, and enter the human body via drinking and eating [5]. Once these toxicants get into the human system, they induce a series of serious diseases such as "black foot disease" [6] and "Itai-Itai disease" [7]. As(V) is present as $\mathrm{HAsO}_{4}{ }^{2-}$ when the solution $\mathrm{pH}$ is 3-6; $\mathrm{AsO}_{4}{ }^{3-}$ dominates at $\mathrm{pH} 7-10$ [8], while $\mathrm{Cd}(\mathrm{II})$ is often present in the solution as Cd(II) [9]. Due to the extremely toxic effects on humans even at low concentration levels, the Chinese Standard "Sanitary Standards for Drinking Water" stipulates that the maximum allowable concentrations of As and Cd should not exceed 0.01 and $0.005 \mathrm{mg} / \mathrm{L}$, respectively [10]. Therefore, the water treatment technologies of $\mathrm{As}(\mathrm{V})$ and $\mathrm{Cd}(\mathrm{II})$ ions have drawn great concerns.

Different treatment technologies including chemical precipitation, ion exchange, and membrane filtration have been developed to eliminate contaminants from wastewater. However, these conventional technologies have numerous disadvantages ranging from the possible generation of secondary wastes and sludge, the high capital cost, and the huge 
power requirements for the operation [11,12]. In contrast with conventional technologies, biosorption is suitable as a simple, efficient, and low-cost process for treating low concentrations of wastewater from several to several hundred $\mathrm{mg} / \mathrm{L}$ [13]. Biosorption refers to an adsorption process using biological materials or biopolymers (including live or dead biomass) as adsorbents [8]. Biosorption materials, especially algae, are abundant in nature either in the terrestrial, marine or freshwater ecosystems and could also be cultivated under optimized conditions [14]. In addition, dead algae do not require nutrition or oxygen [15], which simplifies the experiment procedure. In addition, diverse functional groups such as hydroxyls, carboxylates, amino, and phosphate on the interface of the adsorbents enhance the biosorption capacities of algae to successfully remove various pollutants [16]. Furthermore, there is a possibility of regenerating the used biomass adsorbents after the completion of the biosorption process via desorption using various surfactants [17]. However, the biosorption capacity and efficiency of the adsorbents were not as excellent as the conventional adsorbents. Given the quantities of the adsorbents required to detoxify the wastewater under industrial application [18], there is an urgent need to explore various methods to improve the removal efficiencies of low-cost adsorbents such as algae.

Adsorbent modification is a common method that can rapidly increase the biosorption capacity of adsorbent, including physical modifications and chemical modifications. Physical modifications, such as grinding and boiling, are meant to increase the specific surface area of the adsorbents material [19]. Chemical modifications use chemical reagents such as acids, bases, salts, and organic solvents to change the functional group composition of the surface of the adsorbent [20]. The modification by $\mathrm{NaCl}$ could remove the impurity ions on the surface of the adsorbents, which exposed more binding sites [21]. Moreover, sodium ions can be easily replaced by heavy metal ions without affecting the subsequent biosorption process. The $\mathrm{ZnCl}_{2}$ modification could separate hemicellulose, which contains a variety of functional groups that are beneficial to the biosorption process, from biomass and cause biomass swelling [22]. It has been reported that iron-based adsorbents exhibited a strong affinity for arsenate [23], thus $\mathrm{FeCl}_{3}$ was used to enhance the efficacy of the adsorbent for the effective removal of the As. In addition, $\mathrm{NaOH}$ [24] and $\mathrm{CaCl}_{2}$ [25] have been reported as the modifiers that increase the biosorption capacity of adsorbents for heavy metals to different degrees. Most existing biosorption studies concentrate on the removal of toxic contaminations in mono-component systems [26,27], and the related biosorption mechanism has been thoroughly studied $[9,13,28]$. However, realistic wastewater is much more complex than the mono-component wastewater, which contains various metal ions and other components [29]. The interference and influence of the bimetallic system on the biosorption capacity of algae-based adsorbents are still unclear.

The aims of the study were: (1) to explore the interaction between $\mathrm{As}(\mathrm{V})$ and $\mathrm{Cd}(\mathrm{II})$ during the simultaneous adsorption process; and (2) to develop effective modification methods to improve the adsorption rate of $\mathrm{As}(\mathrm{V})$ and $\mathrm{Cd}(\mathrm{II})$ by the $C$. vulgaris and $S$. platensis. Therefore, the chemical modifications were carried out using $\mathrm{ZnCl}_{2}, \mathrm{NaOH}$, $\mathrm{NaCl}, \mathrm{CaCl}_{2}$, and $\mathrm{FeCl}_{3}$. The effects of $\mathrm{pH}$, adsorbents dosage, contact time, and initial solution concentration in a simultaneous biosorption system were investigated by batch experiments. The adsorbents were characterized using scanning electron microscopy (SEM) and Fourier transform infrared spectroscopy (FTIR) techniques to further elucidate the morphological and physicochemical properties of the adsorbents.

\section{Materials and Methods}

\subsection{Adsorbent Preparation and Modification}

The Chlorella vulgaris (green algae) and Spirulina platensis (cyanobacterium) that were purchased from Zhengzhou Wanbo Chemical Products Co., are dominant algae species in the south of China. Disodium hydrogen arsenate $\left(\mathrm{Na}_{2} \mathrm{HAsO}_{4} \bullet 7 \mathrm{H}_{2} \mathrm{O}\right)$ and cadmium nitrate $\left(\mathrm{Cd}\left(\mathrm{NO}_{3}\right)_{2} \bullet 4 \mathrm{H}_{2} \mathrm{O}\right)$ were purchased from Sigma-Aldrich and Aladdin, respectively, and all the reagents used in the investigation were of analytical grades. 
Chemical modification experiments were carried out using conical flasks $(150 \mathrm{~mL})$ with a $50 \mathrm{~mL}$ solution of each chemical reagent (one of $\mathrm{ZnCl}_{2}, \mathrm{NaOH}, \mathrm{NaCl}, \mathrm{CaCl}_{2}$, and $\mathrm{FeCl}_{3}$ ). To each $50 \mathrm{~mL}$ solution of the $0.1 \mathrm{~mol} / \mathrm{L}$ modification reagent, $2 \mathrm{~g}$ of $\mathrm{C}$. vulgaris and S. platensis powder were added. The suspensions were thoroughly mixed at a speed of 150 rotations per minute (rpm) for $24 \mathrm{~h}$ at a temperature of $25^{\circ} \mathrm{C}$. Afterwards, the modified algae slurry was washed several times with distilled water until all the impurities were successfully eliminated, and was followed by centrifugation. The modified algae biomasses were dried in an oven at a temperature of $80{ }^{\circ} \mathrm{C}$ until a constant weight was obtained and later used in biosorption studies. As a control measure, some C. vulgaris and S. platensis powders were pretreated with only distilled water and labelled as unmodified adsorbents. Before the batch experiments, the modified biomasses were ground using pestle and mortar followed by sieving $(<500 \mu \mathrm{m})$ until the particle sizes became uniform.

\subsection{Characterizations and Analysis}

The samples were characterized with the SEM and FTIR techniques to elucidate the varied morphological and functional groups of characteristics on the adsorbents. The structure and shape of the modified and unmodified C. vulgaris and S. platensis were examined under a scanning electron microscope (Zeiss Ultra Plus, Zeiss, Jena, Germany). The functional groups present on cell walls of the C. vulgaris and S. platensis before and after the modification were determined with the Nicolet 6700 spectrometer (Thermo electron scientific instruments, USA) at wavenumbers from $400-4000 \mathrm{~cm}^{-1}$.

In addition, the concentration of $\mathrm{Cd}$ (II) was measured via flame-atomic absorption spectrometry (ZEEnit700, Analyjena, Jena, Germany) in this study.

The concentration of $\mathrm{As}(\mathrm{V})$ was measured using the colourimetric technique at a wavelength of $880 \mathrm{~nm}$ [30].

\subsection{Biosorption Experiments}

\subsubsection{Effects of Initial $\mathrm{pH}$ and Adsorbents Dosage}

To avoid the co-precipitation on biosorption, the effects of the initial solution $\mathrm{pH}$ on the coexistence of $\mathrm{As}(\mathrm{V})$ and $\mathrm{Cd}(\mathrm{II})$ were investigated in the $\mathrm{pH}$ range from 3.0 to 8.0. The initial solution $\mathrm{pH}$ on the biosorption capacity of $\mathrm{As}(\mathrm{V})$ and $\mathrm{Cd}(\mathrm{II})$ was conducted in a $\mathrm{pH}$ range of 3.0 to 6 based on a previous $\mathrm{pH}$ experiment, where $\mathrm{As}(\mathrm{V})$ and $\mathrm{Cd}(\mathrm{II})$ were present. After studying the adsorbents dosage in the range of $1-4 \mathrm{~g} / \mathrm{L}$ with the $30 \mathrm{mg} / \mathrm{L}$ initial As(V) and Cd(II) solution, it was found that the optimum adsorbents dosage was $4 \mathrm{~g} / \mathrm{L}$ and the optimum contact time was $4 \mathrm{~h}$, which was used in the following experiments. The above experiments were performed using the unmodified C. vulgaris. In the batch experiments, the sorption amount of $\mathrm{As}(\mathrm{V})$ and $\mathrm{Cd}(\mathrm{II})$ was analyzed by measuring the residuals in the supernatant.

\subsubsection{Effects of Different Modifications}

Different modified adsorbents were added to the $30 \mathrm{mg} / \mathrm{L} \mathrm{As}(\mathrm{V})$ and Cd(II) solution to evaluate the efficacy of the modification on the biosorption of the two metal species. The mixture swirled at a speed of $150 \mathrm{rpm}$, temperature of $25^{\circ} \mathrm{C}$, and $150 \mathrm{rpm}$ for $4 \mathrm{~h}$ in a vertical full temperature oscillation incubator (ZQLY-180V, Zhichu Instrument Co., Ltd., Shanghai, China). After settling, $5 \mathrm{~mL}$ of the supernatant was separated using a $0.45 \mu \mathrm{m}$ membrane filter, and the remaining $\mathrm{As}(\mathrm{V})$ and $\mathrm{Cd}(\mathrm{II})$ concentrations were determined.

\subsubsection{Effects of Chemical Reagents Concentration}

The chemical reagents $\left(\mathrm{ZnCl}_{2}\right.$ and $\left.\mathrm{NaCl}\right)$ which showed upregulated effects on the $\mathrm{As}(\mathrm{V})$ and $\mathrm{Cd}(\mathrm{II})$ biosorption rate, were selected for studying the different concentrations of these reagents $(0,0.1,0.5,1.0$, and $2.0 \mathrm{~mol} / \mathrm{L})$. The modified $C$. vulgaris and $S$. platensis were used to investigate the $\mathrm{As}(\mathrm{V})$ and $\mathrm{Cd}(\mathrm{II})$ biosorption rates. Batch experiments were then carried out with the $50 \mathrm{~mL}$ solution of the $\mathrm{As}(\mathrm{V})$ and $\mathrm{Cd}(\mathrm{II})(30 \mathrm{mg} / \mathrm{L})$ with $4 \mathrm{~g} / \mathrm{L}$ biosorbent dosages. 
The biosorption rate $(r)$ of the $\mathrm{As}(\mathrm{V})$ and $\mathrm{Cd}(\mathrm{II})$ after the batch experiments was evaluated according to Equation (1):

$$
r=\frac{\left(C_{t}-C_{0}\right)}{C_{t}} \times 100 \%,
$$

where $C_{t}(\mathrm{mg} / \mathrm{L})$ represents the equilibrium concentration of either $\mathrm{As}(\mathrm{V})$ or $\mathrm{Cd}(\mathrm{II})$, and $C_{0}$ $(\mathrm{mg} / \mathrm{L})$ represents the initial concentration of either $\mathrm{As}(\mathrm{V})$ or $\mathrm{Cd}(\mathrm{II})$.

\subsection{Biosorption Isotherm}

The optimum concentration of chemical reagents $(1 \mathrm{M} \mathrm{NaCl}$ for $C$. vulgaris and $0.5 \mathrm{M}$ $\mathrm{ZnCl}_{2}$ for S. platensis) was used for the biosorption isotherm experiments. The experiments were carried out with the adsorbents dosage of $4 \mathrm{~g} / \mathrm{L}$ with varied initial $\mathrm{As}(\mathrm{V})$ and $\mathrm{Cd}(\mathrm{II})$ concentrations (10-300 mg/L) in a single system. The mixtures were agitated at a speed of $150 \mathrm{rpm}$ and a temperature of $25^{\circ} \mathrm{C}$ for $8 \mathrm{~h}$ to ensure that the biosorption system attained an equilibrium with the initial solution $\mathrm{pH}$ adjusted to 6.0.

The amount of equilibrium biosorption $\left(q_{e}, \mathrm{mg} / \mathrm{g}\right)$ of the $\mathrm{As}(\mathrm{V})$ and $\mathrm{Cd}(\mathrm{II})$ is calculated following Equation (2):

$$
q_{e}=\frac{V \times\left(C_{t}-C_{0}\right)}{W},
$$

where $V(\mathrm{~L})$ denotes the volume of the solution, $W(\mathrm{~g})$ represents the weight of dry adsorbents, and $C_{0}(\mathrm{mg} / \mathrm{L})$ represents the initial $\mathrm{As}(\mathrm{V})$ and $\mathrm{Cd}(\mathrm{II})$ concentration.

The Langmuir and Freundlich models in Equations (3) and (4), respectively were employed to evaluate the biosorption isotherms to assess the performance of the adsorbents.

$$
\begin{gathered}
q_{e}=\frac{q_{\max } K_{L} C_{e}}{1+K_{L} C_{e}}, \\
\log q_{e}=\log \frac{C_{e}}{n}+\log K_{F},
\end{gathered}
$$

where $q_{\max }(\mathrm{mg} / \mathrm{g})$ represents the maximum adsorption capacity, $q_{e}(\mathrm{mg} / \mathrm{g})$ is the equilibrium adsorbed amount of the $\mathrm{As}(\mathrm{V})$ and $\mathrm{Cd}(\mathrm{II})$, and $C_{e}(\mathrm{mg} / \mathrm{L})$ is the equilibrium concentration of the solute. In the Langmuir isotherm model (Equation (3)), $K_{L}$ represents the Langmuir constant regarding the energy of biosorption, whereas the $K_{F}$ and $1 / n$ are the Freundlich constants (Equation (4)), respectively.

\subsection{Biosorption Kinetics}

Biosorption kinetics studies were conducted with $50 \mathrm{~mL}$ of the solution containing $30 \mathrm{mg} / \mathrm{L}$ of $\mathrm{As}(\mathrm{V})$ and $\mathrm{Cd}(\mathrm{II})$ with $4 \mathrm{~g} / \mathrm{L}$ of the modified adsorbents using initial $\mathrm{pH}$ 6. The mixtures were agitated at a speed of $150 \mathrm{rpm}$ at a temperature of $25^{\circ} \mathrm{C}$ with varied time intervals from $5 \mathrm{~min}$ to $8 \mathrm{~h}$, depending on the appropriate equilibrium time.

The biosorption kinetic data on the removal of $\mathrm{As}(\mathrm{V})$ and $\mathrm{Cd}(\mathrm{II})$ were assessed via pseudo-first-order and pseudo-second-order models.

The pseudo-first-order kinetic model is expressed in Equation (5) as follows:

$$
\ln \left(q_{e}-q_{t}\right)=\ln q_{e}-k_{1} t
$$

While the pseudo-second-order kinetic model is given as shown in Equation (6):

$$
\frac{t}{q_{t}}=\frac{1}{k_{2} q_{e}^{2}}+\frac{t}{q_{e}}
$$

where $q_{e}$ and $q_{t}$ represent the equilibrium biosorption capacity $(\mathrm{mg} / \mathrm{g})$ and the biosorption capacity at $t(\mathrm{~min}), k_{1}$, and $k_{2}$ are the rate constants for the pseudo-first-order and pseudosecond-order models, correspondingly. All the experiments were conducted in duplicate and the averages were used for the analysis. 


\section{Results and Discussion}

\subsection{Effects of Initial $\mathrm{pH}$ and Adsorbents Dosage}

The initial $\mathrm{pH}$ of the metal solution is a key influencing factor during the biosorption process. The influence of the initial solution $\mathrm{pH}$ was investigated on the simultaneous removal of $\mathrm{As}(\mathrm{V})$ and $\mathrm{Cd}(\mathrm{II})$ using $\mathrm{C}$. vulgaris, which was investigated under $\mathrm{pH}$ conditions of 3.0-6.0. The results in Figure 1a showed that with an increase in the initial $\mathrm{pH}$ from 3.0 to 6.0 involving the Cd-As solution, there was no change in the concentration of $\mathrm{Cd}(\mathrm{II})$. However, it sharply decreased when the $\mathrm{pH}$ increased above 6.0. Additionally, it was reported that $\mathrm{Cd}$ (II) started to form $\mathrm{Cd}(\mathrm{OH})_{2}$ precipitation at $\mathrm{pH}$ values above 8.0 [31]. Moreover, it suggested that the precipitation threshold of $\mathrm{Cd}$ (II) shifts towards a low $\mathrm{pH}$ in the existence of $\mathrm{As}(\mathrm{V})$. This was probably due to the fact that $\mathrm{Cd}(\mathrm{II})$ and $\mathrm{AsO}_{4}{ }^{3-}$ formed $\mathrm{Cd}_{3}\left(\mathrm{AsO}_{4}\right)_{2}$ complexed with a solubility product constant value of $\mathrm{K}_{\mathrm{sp}}=5.13 \times 10^{-34}$ [32]. Similar results have been reported by Jiang, Lv, Luo, Yang, Lin, Hu, Zhang, and Zhang [5], which showed that $0.1 \mathrm{mM} \mathrm{Cd}^{2+}$ barely co-precipitated with $0.5 \mathrm{mM} \mathrm{As}(\mathrm{V})$ below $\mathrm{pH} 7$. Consequently, the coexistence of $\mathrm{As}(\mathrm{V})$ and $\mathrm{Cd}(\mathrm{II})$ was influenced by the initial solution $\mathrm{pH}$ together with the concentration of $\mathrm{As}(\mathrm{V})$ and $\mathrm{Cd}(\mathrm{II})$. To eliminate the effect of coprecipitation during the biosorption processes, the $\mathrm{pH}$ values were adjusted between 3 to 6 . The results in Figure $1 \mathrm{~b}$ showed opposite trends regarding the biosorption of $\mathrm{As}(\mathrm{V})$ and $\mathrm{Cd}(\mathrm{II})$ in the single system. The biosorption rate of $\mathrm{Cd}(\mathrm{II})$ was relatively low at $\mathrm{pH} 3$, whereas it rapidly increased with the $\mathrm{pH}$ rise from 3 to 4 . As the $\mathrm{pH}$ continued to increase, the biosorption rate gradually increased and eventually exceeded $90 \%$. This phenomenon could be ascribed to the electrostatic attraction between $\mathrm{Cd}(\mathrm{II})$ and the various functional groups present on adsorbents surfaces. In low- $\mathrm{pH}$ solutions, the $\mathrm{H}^{+}$of high concentration could compete for biosorption sites with $\mathrm{Cd}(\mathrm{II})$. An increase in $\mathrm{pH}$ gave rise to the deprotonation of functional groups of the adsorbents. Hence, a high affinity for positively charged $\mathrm{Cd}(\mathrm{II})$ ions [33]. The biosorption rate of $\mathrm{As}(\mathrm{V})$ and $\mathrm{Cd}(\mathrm{II})$ decreased in the binary system (Figure 1b), possibly due to the competition of biosorption sites, but the basic trend remained unchanged in the single system. When the initial $\mathrm{pH}$ was 6 , the $\mathrm{Cd}(\mathrm{II})$ biosorption rate reached the maximum(above $90 \%$ ), and the $\mathrm{As}(\mathrm{V})$ was maintained at $2 \%$. Therefore, $\mathrm{pH} 6$ was selected to be the test condition of the following experiments. The findings are indicative of the fact that the removal of $\mathrm{Cd}(\mathrm{II})$ and $\mathrm{As}(\mathrm{V})$ is exceedingly dependent on the $\mathrm{pH}$.

The results of $C$. vulgaris dosage on the simultaneous biosorption are presented in Figure 1c, which suggested that the biosorption efficiency for both $\mathrm{As}(\mathrm{V})$ and $\mathrm{Cd}(\mathrm{II})$ is dependent on the $C$. vulgaris adsorbents dosage. A possible reason could be that more biosorption sites for heavy metals were available at higher $C$. vulgaris dosage [34]. However, the biosorption capacities for $\mathrm{As}(\mathrm{V})$ and $\mathrm{Cd}(\mathrm{II})$ decreased intensely with the increasing adsorbents dosage, which might be caused by the fixed total amount of ions. Therefore, for practical applications, it is essential to consider the optimum adsorbents dosage for an effective reduction in the concentration of the pollutants. When the dosage of $C$. vulgaris was $2.0 \mathrm{~g} / \mathrm{L}$, the removal of $\mathrm{Cd}(\mathrm{II})$ was above $80 \%$, and $\mathrm{As}(\mathrm{V})$ reached the maximum. Therefore, the adsorbents dosage of $2.0 \mathrm{~g} / \mathrm{L}$ was chosen as the optimum dosage for the subsequent experiments, including unmodified and modified algae adsorbents. 

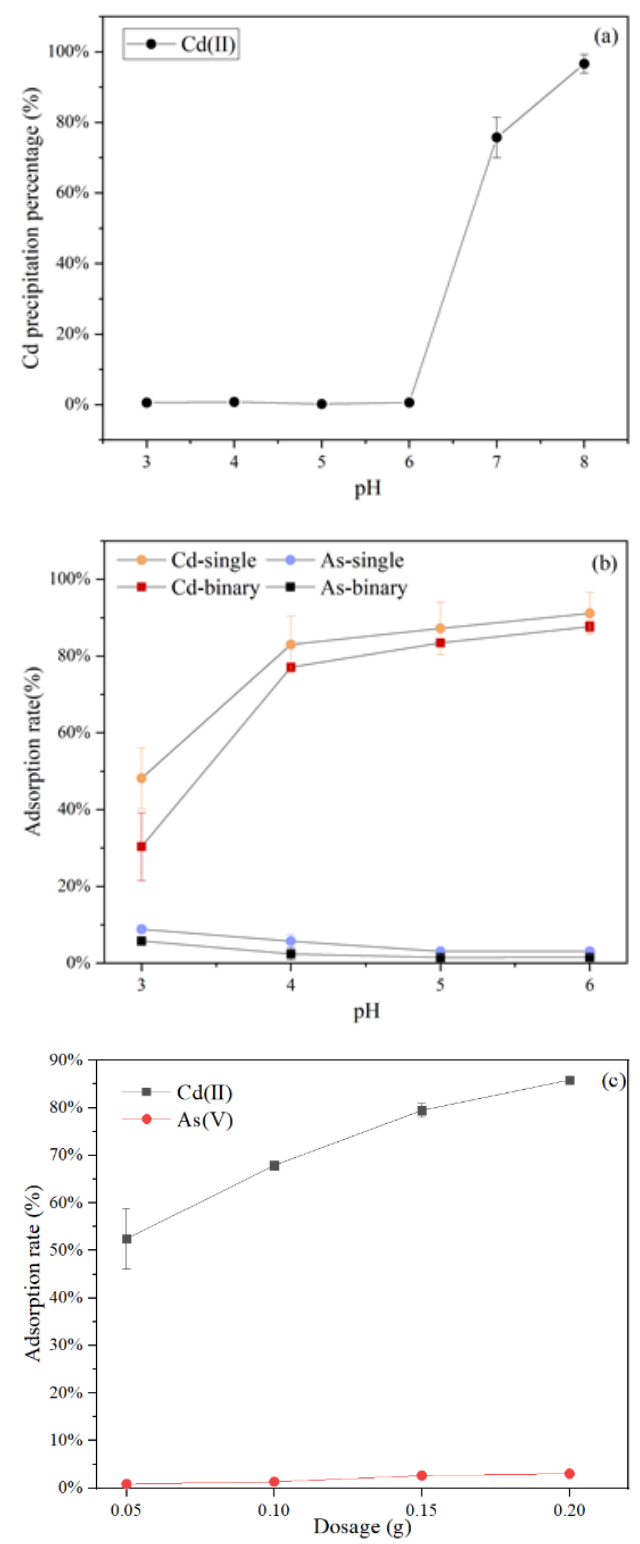

Figure 1. The image of the $\mathrm{As}(\mathrm{V})$ and $\mathrm{Cd}(\mathrm{II})$ precipitation curves: (a) Effects of $\mathrm{pH}$ on co-precipitation, (b) biosorption by C. vulgaris for the single and binary solution systems, and (c) adsorbents dosage on adsorption by $C$. vulgaris for the binary solution systems.

\subsection{Biosorption Efficiency of Different Modified Adsorbents}

The different chemical modifications on the removal of C. vulgaris (Figure 2a) and S. platensis (Figure $2 \mathrm{~b}$ ) were investigated with five $0.1 \mathrm{~mol} / \mathrm{L}$ modifiers including $\mathrm{ZnCl}_{2}$, $\mathrm{NaOH}, \mathrm{NaCl}, \mathrm{CaCl}_{2}$, and $\mathrm{FeCl}_{3}$.

The $\mathrm{NaOH}$ modified adsorbents showed the enhanced removal of $\mathrm{Cd}(\mathrm{II})$ by both algae but had little effect on the removal of $\mathrm{As}(\mathrm{V})$. The hemicellulose in the biomass will be softened due to the hydrolysis reaction by alkaline compounds such as $\mathrm{NaOH}$. This could be attributed to the formation of hydroxyl $(-\mathrm{OH})$ and carboxylic $(-\mathrm{COOH})$ groups present in the modified algae. Hence, facilitating the $\mathrm{Cd}$ (II) removal [35]. Similar results were observed from $\mathrm{CaCl}_{2}$ in this study, which increased the removal of $\mathrm{Cd}(\mathrm{II})$ by $\mathrm{C}$. vulgaris and S. platensis but reduced the removal of $\mathrm{As}(\mathrm{V})$. In contrast to the modification by $\mathrm{NaOH}$ and $\mathrm{CaCl}_{2}$, the algae modified with $\mathrm{FeCl}_{3}$ could achieve almost $100 \%$ removal of $\mathrm{As}(\mathrm{V})$. However, it could only reach $8 \%$ and $9 \%$ removal of $\mathrm{Cd}(\mathrm{II})$, respectively, which was much lower than that of unmodified algae. The mechanism of As(V) biosorption could be the 
potential ligand exchange reactions between the $\mathrm{As}(\mathrm{V})$ and the surface hydroxyl groups in harmony with the Fe atoms [36].
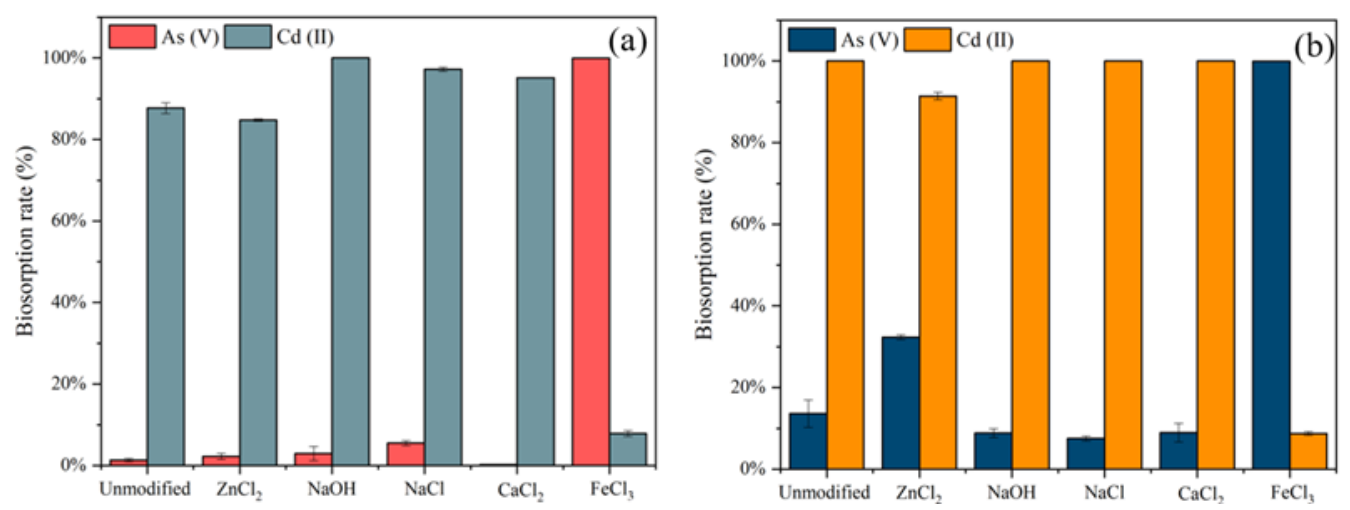

Figure 2. Biosorption rates (\%) for $\mathrm{As}(\mathrm{V})$ and $\mathrm{Cd}(\mathrm{II})$ by (a) unmodified and chemically modified C. vulgaris, and (b) unmodified and chemically modified S. platensis.

Moreover, $\mathrm{NaCl}$ and $\mathrm{ZnCl}_{2}$ had a significant increase in the biosorption of $C$. vulgaris and S. platensis, respectively. The $\mathrm{NaCl}$ modification of $C$. vulgaris increased the $\mathrm{Cd}(\mathrm{II})$ removal from $93 \%$ to $97 \%$ and $\mathrm{As}(\mathrm{V})$ from $1 \%$ to $5 \%$. The increase in biosorption efficiency after modification with $\mathrm{NaCl}$ could be attributed to an ion exchange process. After the modification with $\mathrm{NaCl}, \mathrm{Na}^{+}$may have remained on the surfaces of the algae cell walls, and then the cationic ions exchanged with the metal ions during the biosorption process [19]. Additionally, a notable difference was observed in the biosorption rate of $\mathrm{ZnCl}_{2}$ on $S$. platensis, which increased the As removal from $13.6 \%$ to $32.3 \%$ but decreased the Cd(II) from $100 \%$ to $91 \%$. Two reasons may account for the enhanced biosorption efficiency: (a) These could be the swelling of the hemicelluloses and cellulose during the activation of the biomass [37]; (b) the modification of S. platensis with $\mathrm{ZnCl}_{2}$ increased the number of biosorption sites, but due to the competition effect between $\mathrm{As}(\mathrm{V})$ and $\mathrm{Cd}(\mathrm{II}), \mathrm{As}(\mathrm{V})$ might occupy some of the $\mathrm{Cd}(\mathrm{II})$ biosorption sites, resulting in a decrease in the biosorption rate of Cd(II).

\subsection{Effects of the Concentration of Modification Reagents}

Different modification reagents were employed for the modification of the algae biomasses and the most effective reagents were chosen for subsequent studies. The modification by $\mathrm{NaCl}$ and $\mathrm{ZnCl}_{2}$ modification recorded the maximum effect on the removal of $\mathrm{As}(\mathrm{V})$ and $\mathrm{Cd}(\mathrm{II})$ by $\mathrm{C}$. vulgaris and S. platensis, correspondingly. Therefore, the concentration of the two modification reagents was varied as follows $0,0.1,0.5,1.0$, and $2.0 \mathrm{M}$ and the results were shown in Figure 3.

In Figure 3a, an increase in the biosorption rate of $\mathrm{As}(\mathrm{V})$ and $\mathrm{Cd}(\mathrm{II})$ was observed with $\mathrm{NaCl}$-modified C. vulgaris. With the rise in $\mathrm{NaCl}$ concentration to $0.1 \mathrm{M}$, the $\mathrm{As}(\mathrm{V})$ removal of $\mathrm{NaCl}$ modified C. vulgaris increased from $1.3 \%$ to $5.2 \%$ and $\mathrm{Cd}(\mathrm{II})$ increased from $92.7 \%$ to $97.6 \%$. This increasing trend was maintained up to $1.0 \mathrm{~mol} / \mathrm{L}$ but dropped at $2.0 \mathrm{~mol} / \mathrm{L}$. Therefore, $1.0 \mathrm{~mol} / \mathrm{L}$ was the optimum modified concentration for C. vulgaris. A higher concentration of $\mathrm{NaCl}$ could negatively affect the biosorption of $\mathrm{As}(\mathrm{V})$ and $\mathrm{Cd}(\mathrm{II})$. In Figure $3 \mathrm{~b}$, the rise in the concentration of $\mathrm{ZnCl}_{2}$ from 0 to $2 \mathrm{~mol} / \mathrm{L}$, led to a slight decrease in the removal of $\mathrm{Cd}(\mathrm{II})$, while the removal of $\mathrm{As}(\mathrm{V})$ increased marginally.

As for S. platensis (Figure 3c), the modification of $\mathrm{NaCl}$ had no remarkable effect on the biosorption of $\mathrm{As}(\mathrm{V})$ and $\mathrm{Cd}(\mathrm{II})$, the difference between the 0.1 to $2 \mathrm{M}$ concentrations was not significant. However, in Figure $3 \mathrm{~d}$, the maximum $\mathrm{As}(\mathrm{V})$ removal efficiency onto S. platensis was achieved using $1 \mathrm{M} \mathrm{ZnCl}_{2}$ for modification. The biosorption rate of $\mathrm{Cd}(\mathrm{II})$ decreased from $100 \%$ to $73 \%$ with the increasing concentration, while the biosorption rate of $\mathrm{As}(\mathrm{V})$ increased from $13 \%$ to $50 \%$. At a higher $\mathrm{ZnCl}_{2}$ concentration $(2 \mathrm{M})$, the $\mathrm{As}(\mathrm{V})$ 
biosorption rate decreased to $46 \%$. The reason may be that the modification improved the porosity development of the adsorbent. Additionally, $\mathrm{As}(\mathrm{V})$ interacted more easily with the various functionalities on the cell walls of the adsorbent, while the removal of $\mathrm{Cd}$ (II) decreased, attributable to the nonexistence of the available biosorption sites.
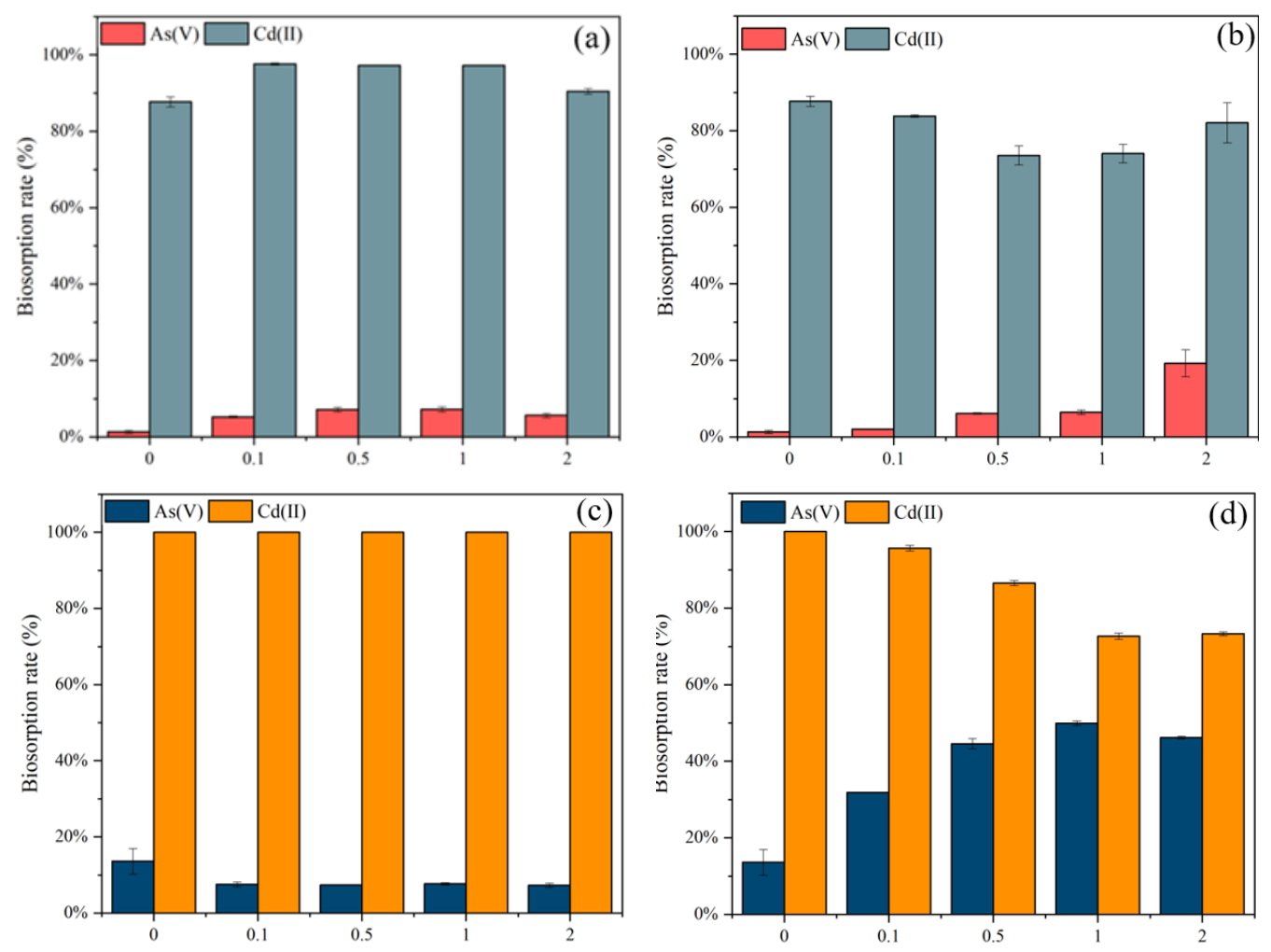

Figure 3. Biosorption rates (\%) for $\mathrm{As}(\mathrm{V})$ and $\mathrm{Cd}(\mathrm{II})$ by different concentrations of (a) $\mathrm{NaCl}$ and (b) $\mathrm{ZnCl}_{2}$ modified $C$. vulgaris, and (c) $\mathrm{NaCl}$ and (d) $\mathrm{ZnCl}_{2}$ modified S. platensis.

To achieve a balance in the removal efficiency of $\mathrm{As}(\mathrm{V})$ and $\mathrm{Cd}(\mathrm{II})$ and to maximize the total biosorption rate, $0.5 \mathrm{~mol} / \mathrm{L} \mathrm{ZnCl}_{2}$ modified S. platensis and $1 \mathrm{~mol} / \mathrm{L} \mathrm{NaCl}$ modified $C$. vulgaris were selected for the follow-up experiments.

\subsection{Biosorption Kinetic Analysis}

The comparison for the evaluation of the kinetic parameters between the two algae samples is presented in Figure 4a. The biosorption capacity of $\mathrm{As}(\mathrm{V})$ and $\mathrm{Cd}(\mathrm{II})$ reached about $90 \%$ of the equilibrium biosorption capacity at the contact time of $2 \mathrm{~h}$. Thereafter, as a result of the gradual decrease in the available active sites, the uptake of the ions by the adsorbent gradually reduced with the increasing contact time, and at $4 \mathrm{~h}$, the biosorption reached equilibrium.

To analyze the kinetics of the biosorption kinetics of $\mathrm{As}(\mathrm{V})$ and $\mathrm{Cd}(\mathrm{II})$ onto $\mathrm{NaCl}$ modified C. vulgaris and $\mathrm{ZnCl}_{2}$ modified S. platensis, the experimental data were fitted with both the pseudo-first-order and pseudo-second-order models. The values for the kinetic constant parameters for $\mathrm{As}(\mathrm{V})$ and $\mathrm{Cd}(\mathrm{II})$ biosorption are listed in Table 1. From Table 1, the values of the $\mathrm{R}^{2}$ for $\mathrm{As}(\mathrm{V})$ and $\mathrm{Cd}(\mathrm{II})$ obtained from the evaluation of the pseudo-second-order model were much higher (over 0.99) compared to the values obtained from the pseudo-first-order kinetic model for the $\mathrm{NaCl}$ modified C. vulgaris and $\mathrm{ZnCl}_{2}$ modified S. platensis. The $q_{\mathrm{e}}$ values (calculated) for $\mathrm{As}(\mathrm{V})$ and $\mathrm{Cd}(\mathrm{II})$ obtained from the pseudo-second-order model using the two adsorbents corroborated with the experimental $q_{e}$ values $(0.33$ and $7.51 \mathrm{mg} / \mathrm{g}$ for the $\mathrm{NaCl}$ modified C. vulgaris, respectively, and 3.41 and $6.11 \mathrm{mg} / \mathrm{g}$ for the $\mathrm{ZnCl}_{2}$ modified S. platensis, correspondingly). Based on these results, 
the PSO model best described the biosorption which was largely influenced by a chemical process [34].
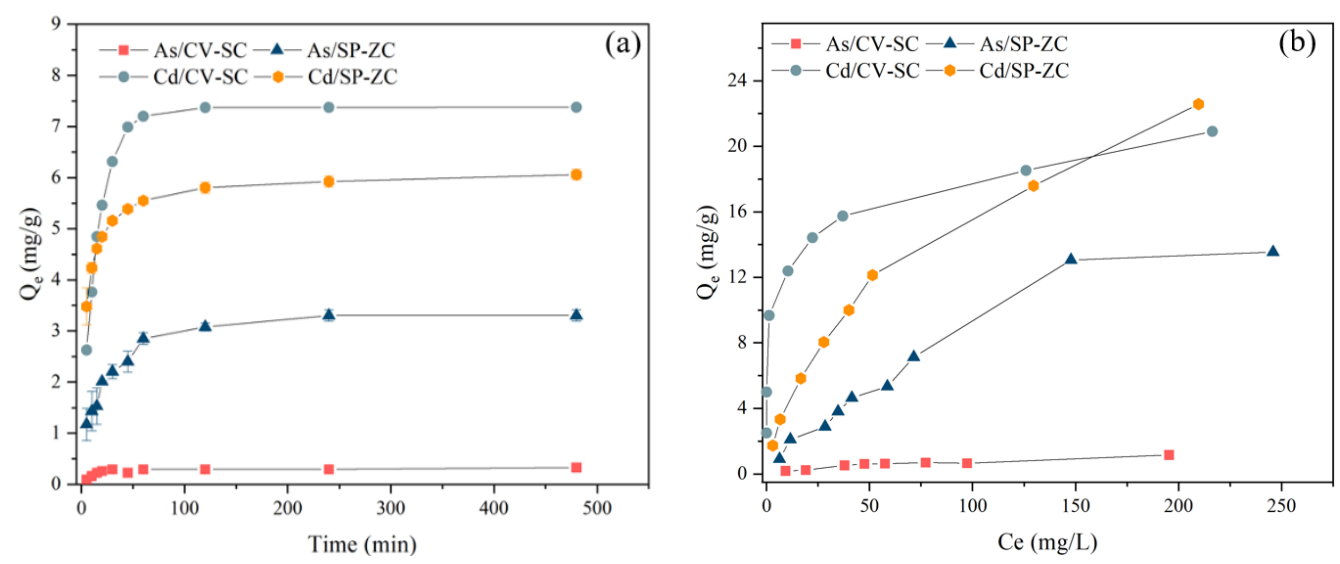

Figure 4. Effects of (a) contact time and (b) initial concentration on biosorption for $\mathrm{As}(\mathrm{V})$ and $\mathrm{Cd}(\mathrm{II})$ by $\mathrm{NaCl}$ modified $\mathrm{C}$. vulgaris and $\mathrm{ZnCl}_{2}$ modified S. platensis.

Table 1. Kinetic model parameters of $\mathrm{As}(\mathrm{V})$ and $\mathrm{Cd}(\mathrm{II})$ biosorption onto the $\mathrm{NaCl}$ modified C. vulgaris and S. platensis.

\begin{tabular}{ccccc}
\hline \multirow{2}{*}{ Parameter } & \multicolumn{2}{c}{$\mathbf{N a C l}$ Modified C. vulgaris } & \multicolumn{2}{c}{$\mathbf{Z n C l}_{\mathbf{2}}$ Modified S. platensis } \\
\cline { 2 - 5 } & As & Cd & As & Cd \\
\hline Pseudo-first-order & & & & \\
$K_{1}$ & $2.63 \times 10^{-5}$ & $1.50 \times 10^{-4}$ & $3.88 \times 10^{-6}$ & $9.30 \times 10^{-6}$ \\
$q_{e}$ & 0.99 & 3.34 & 5.64 & 2.96 \\
$\mathrm{R}^{2}$ & 0.31 & 0.86 & 0.46 & 0.37 \\
\hline Pseudo-second-order & & & & \\
$K_{2}$ & 0.28 & 0.02 & 0.21 & 0.03 \\
$q_{e}$ & 0.33 & 7.51 & 3.4089 & 6.111 \\
$\mathrm{R}^{2}$ & 0.9970 & 0.9996 & 0.9994 & 0.9999 \\
\hline
\end{tabular}

\subsection{Biosorption Isotherm}

The biosorption capacities for $\mathrm{As}(\mathrm{V})$ and $\mathrm{Cd}(\mathrm{II})$ for the various initial concentrations (10-300 mg/L) were investigated individually by biosorption isotherm experiments. As shown in Figure $4 b$, under the experimental condition, the highest biosorption capacities recorded for $\mathrm{As}(\mathrm{V})$ and $\mathrm{Cd}(\mathrm{II})$ were found to be 1.16 and $20.91 \mathrm{mg} / \mathrm{g}$ for the $\mathrm{NaCl}$ modified $\mathrm{C}$. vulgaris, respectively, and 13.55 and $22.58 \mathrm{mg} / \mathrm{g}$ were for the $\mathrm{ZnCl}_{2}$ modified $S$. platensis, respectively.

Additionally, the effectiveness of the $\mathrm{NaCl}$ modified $C$. vulgaris and $\mathrm{ZnCl}_{2}$ modified $S$. platensis for the efficient removal of $\mathrm{As}(\mathrm{V})$ and $\mathrm{Cd}(\mathrm{II})$, was examined using the Langmuir and Freundlich isotherm models. The various correlation coefficients are presented in Table 2. As shown in Table 2, the As(V) and Cd(II) biosorption data fitted the Freundlich isotherm model $\left(\mathrm{R}^{2}, \mathrm{Cd}=0.990, \mathrm{As}=0.936\right)$ well for the $\mathrm{NaCl}$ modified $\mathrm{C}$. vulgaris, based on the regression coefficients compared to the Langmuir isotherm model. These results suggested that the biosorption of $\mathrm{Cd}(\mathrm{II})$ by the $\mathrm{NaCl}$ modified $\mathrm{C}$. vulgaris occurs on a heterogeneous surface via multilayer sorption [13].

As for the $\mathrm{ZnCl}_{2}$ modified S. platensis, the $\mathrm{As}(\mathrm{V})$ biosorption behaviour fitted the Langmuir isotherm $\left(R^{2}, A s=0.986\right)$ better, which suggested that the nature of the biosorption was homogenous via the monolayer biosorption [13]. In contrast, the Cd(II) biosorption behaviour fitted the Freundlich isotherm $\left(R^{2}, C d=0.992\right)$ better, which was indicated by the higher $\mathrm{R}^{2}$ obtained for the Langmuir isotherm (Table 2). This result could be due to the following reasons: (1) The modification of $\mathrm{ZnCl}_{2}$ might have resulted in an even distribution of the binding sites on the $\mathrm{ZnCl}_{2}$ modified S. platensis surface [38]; (2) there is a 
possibility that two metal ions might have formed different complexes with the functional groups on the surface of the $\mathrm{ZnCl}_{2}$ modified S. platensis [39].

Table 2. Isotherm model parameters for $\mathrm{As}(\mathrm{V})$ and $\mathrm{Cd}(\mathrm{II})$ biosorption onto $\mathrm{NaCl}$ modified $\mathrm{C}$. vulgaris and $\mathrm{ZnCl}_{2}$ modified S. platensis.

\begin{tabular}{ccccc}
\hline \multirow{2}{*}{ Parameter } & \multicolumn{2}{c}{ NaCl Modified C. vulgaris } & \multicolumn{2}{c}{$\mathbf{Z n C l}_{\mathbf{2}}$ Modified S. platensis } \\
\cline { 2 - 5 } & As & Cd & As & Cd \\
\hline Langmuir & & & & \\
$q_{m}$ & 1.61 & 17.60 & 24.88 & 29.37 \\
$K_{L}$ & $1.06 \times 10^{-2}$ & 0.62 & $5.60 \times 10^{-3}$ & $1.36 \times 10^{-2}$ \\
$\mathrm{R}^{2}$ & 0.9211 & 0.7498 & 0.9634 & 0.9888 \\
\hline Freundlich & & & \\
$K_{f}$ & $6.40 \times 10^{-2}$ & 8.93 & 0.42 & 1.44 \\
$N$ & 1.83 & 6.45 & 1.54 & 1.93 \\
$\mathrm{R}^{2}$ & 0.9356 & 0.9904 & 0.9391 & 0.9918 \\
\hline
\end{tabular}

The maximum biosorption capacity obtained from the Langmuir for the $\mathrm{ZnCl}_{2}$ modified S. platensis for $\mathrm{As}(\mathrm{V})$ and $\mathrm{Cd}(\mathrm{II})$ was 24.8 and $29.4 \mathrm{mg} / \mathrm{g}$, correspondingly, which were much greater than the $\mathrm{NaCl}$ modified C. vulgaris. This suggested that the $\mathrm{ZnCl}_{2}$ modified S. platensis could be effectively used to eliminate $\mathrm{As}(\mathrm{V})$ and $\mathrm{Cd}(\mathrm{II})$ from wastewater simultaneously.

\subsection{Adsorbents Characterization}

The distinctly different morphological features of unmodified common C. vulgaris and S. platensis is shown in Figure 5. The surface of $C$. vulgaris is relatively flat and uniformly distributed with many round particles (Figure 5a), with many tiny pores and cavities between these particles. In contrast, S. platensis particles have an irregular shape, with many elongated grooves and larger cavities on the surface (Figure 5c). This structure of S. platensis may allow heavy metal molecules to penetrate more easily into the internal structure and interact with the functional groups on its surface.

The scanning electron microscopy images showed that the uniform pore structure of the surface of $C$. vulgaris disappeared after modification by $\mathrm{ZnCl}_{2}$ (Figure $5 \mathrm{~b}$ ). The particles were agglomerated, showing more bumps, larger cavities, and rougher surface structures. The sizes of the particles were also reduced in terms of appearance. A similar phenomenon was observed from $\mathrm{ZnCl}_{2}$ modified S. platensis (Figure $5 \mathrm{~d}$ ), where the elongated surface grooves turned into larger cavities and presented a rougher morphology. Generally, the $\mathrm{ZnCl}_{2}$ modification may have increased the specific surface area of both green algae particles, thus enhancing their biosorption capacity for heavy metals.

The identification of the various functional groups present on the algae surface was carried out via FTIR spectroscopy. Figure 6 shows the FTIR graph of unmodified and chemically modified algae samples. The FTIR spectroscopic graph indicated an intensity peak at around $3294 \mathrm{~cm}^{-1}$ in all the samples, suggesting the presence of $\mathrm{O}-\mathrm{H}$ and $\mathrm{N}-$ $\mathrm{H}$. The peaks around $2926 \mathrm{~cm}^{-1}$ were ascribed to the $\mathrm{C}-\mathrm{H}$ stretching vibrations, which could be found in cellulose and lignin [40]. Additionally, the peaks near $1660 \mathrm{~cm}^{-1}$ were ascribed to the $\mathrm{C}=\mathrm{O}$ asymmetric stretching. Compared to unmodified $C$. vulgaris, the strength of the $\mathrm{O}-\mathrm{H}, \mathrm{C}-\mathrm{H}$, and $\mathrm{C}=\mathrm{O}$ stretching band for $\mathrm{NaCl}$ modified $\mathrm{C}$. vulgaris increased (Figure 6a), indicating the increase of these functional groups. Similarly, the $\mathrm{C}-\mathrm{H}$ and $\mathrm{C}=\mathrm{O}$ functionalities in the $\mathrm{ZnCl}_{2}$ modified S. platensis exhibited an increased intensity (Figure 6b), demonstrating that the $\mathrm{ZnCl}_{2}$ modification increased the surface area and the functional groups. The FTIR graph showed that the C. vulgaris and S. platensis surfaces were occupied by the hydroxyl, carboxylate, amino, and amide groups, which had a remarkable role during the biosorption process [41,42]. 

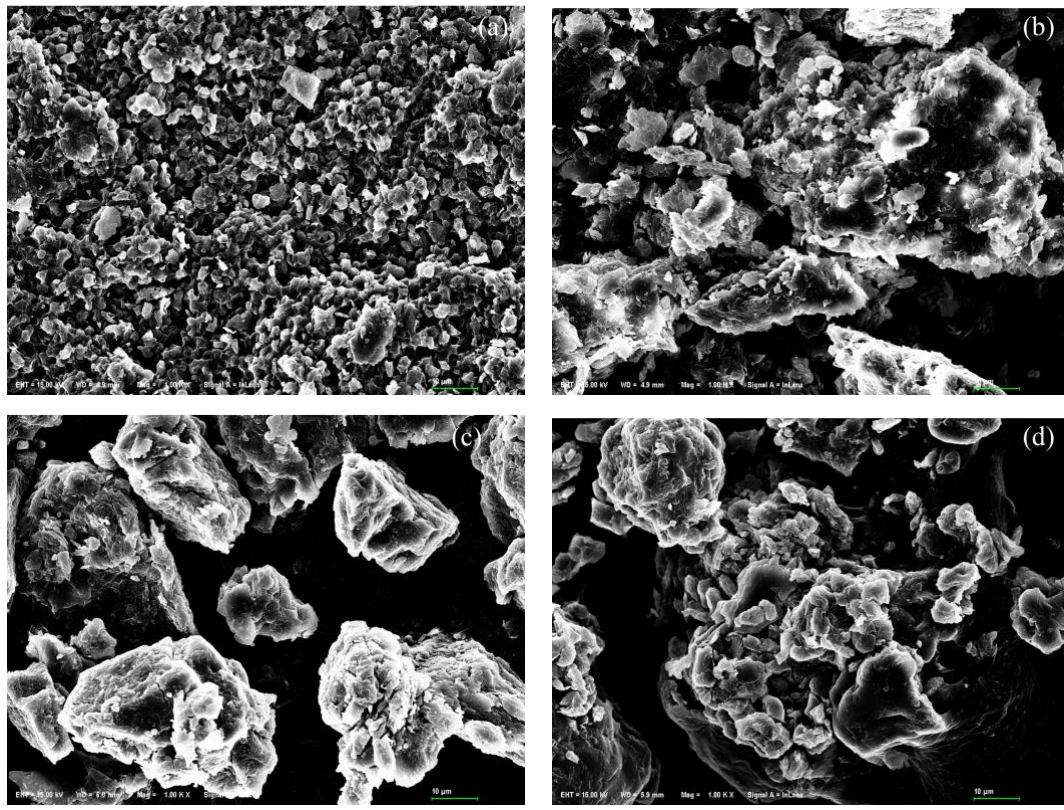

Figure 5. SEM image of (a) unmodified and (b) $\mathrm{ZnCl}_{2}$ modified C. vulgaris, and (c) unmodified and (d) $\mathrm{ZnCl}_{2}$ modified S. platensis.
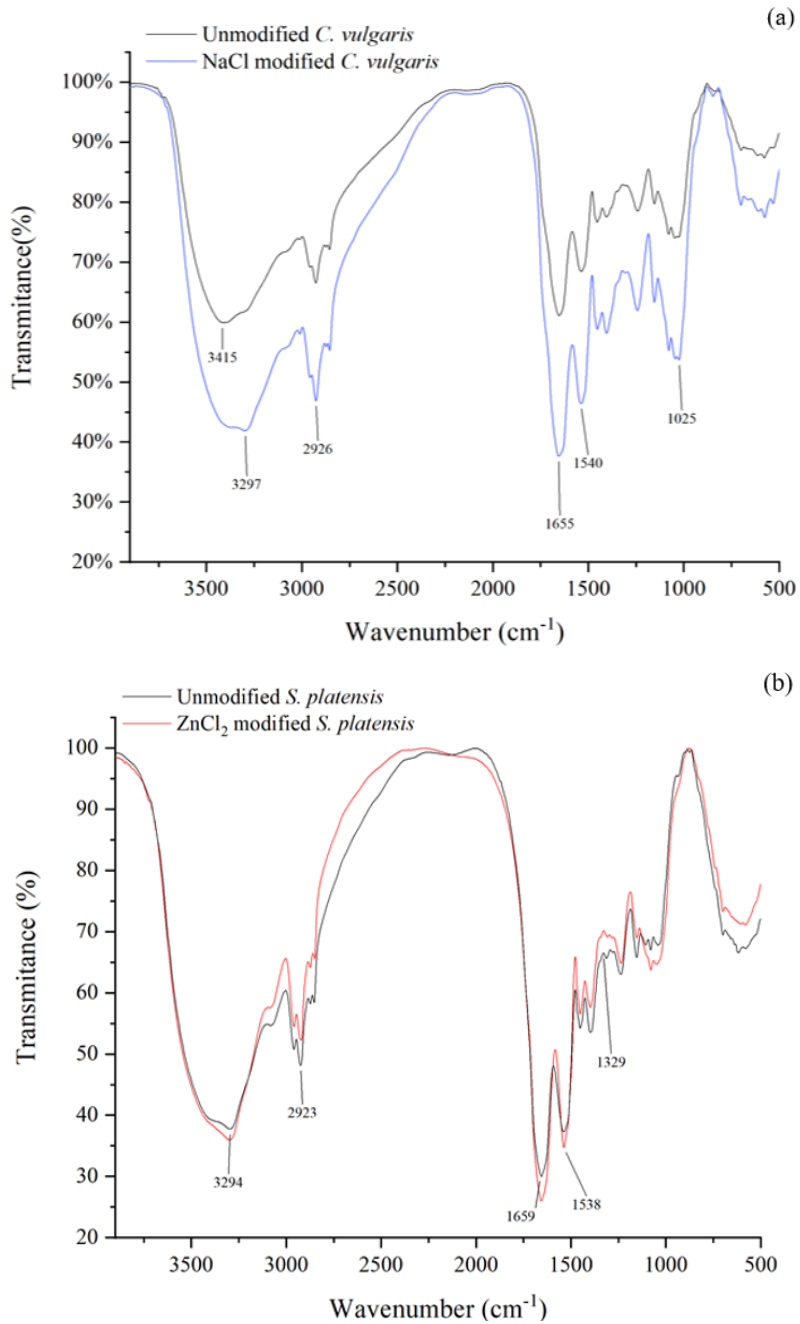

Figure 6. FTIR spectra of (a) C. vulgaris and (b) S. platensis before and after modification. 


\section{Conclusions}

In this study, the effects of different chemical modifications on the simultaneous biosorption of $\mathrm{As}(\mathrm{V})$ and $\mathrm{Cd}(\mathrm{II})$ by two green algae were investigated. The results revealed that the effect of modification was related to the type of algae, the chemical reagents, and the reagent concentration. The biosorption rate of S. platensis for $\mathrm{As}(\mathrm{V})$ and $\mathrm{Cd}(\mathrm{II})$ $(13.58 \%$ and $100 \%)$ was higher than that for C. vulgaris $(1.32 \%$ and $92.68 \%)$, which may be related to its rougher surface structure and larger specific surface area. Moreover, $1 \mathrm{M}$ $\mathrm{NaCl}$ and $0.5 \mathrm{M} \mathrm{ZnCl}_{2}$ were found to be the optimal chemical reagents to improve the biosorption performance of $C$. vulgaris and S. platensis, correspondingly. The biosorption rate of $\mathrm{NaCl}$ modified C. vulgaris and $\mathrm{ZnCl}_{2}$ modified S. platensis for $\mathrm{As}(\mathrm{V})$ and $\mathrm{Cd}(\mathrm{II})$ were $7.22 \%$ and $97.23 \%, 44.57 \%$, and $86.58 \%$, respectively. The biosorption of $\mathrm{As}(\mathrm{V})$ and $\mathrm{Cd}(\mathrm{II})$ at $30 \mathrm{mg} / \mathrm{L}$ exhibited competitive effects in the binary system. The modification improved the biosorption efficiency of the adsorbent for $\mathrm{As}(\mathrm{V})$ and $\mathrm{Cd}(\mathrm{II})$ but did not change this competitive effect. Overall, in the low concentration range, this work provided an effective and low-cost biosorption technology to simultaneously remove $\mathrm{As}(\mathrm{V})$ and $\mathrm{Cd}(\mathrm{II})$.

Author Contributions: Conceptualization, L.P.; methodology, W.L. and L.P.; validation, Y.X., C.L., and L.P.; formal analysis, W.L.; investigation, W.L.; resources, L.P. and Y.X.; data curation, W.L.; writing - original draft preparation, W.L. and B.I.M.; writing—review and editing, L.P., Y.X. and C.L.; visualization, W.L.; supervision, L.P., Y.X. and C.L.; funding acquisition, L.P. All authors have read and agreed to the published version of the manuscript.

Funding: This research was funded by the Natural Science Foundation of Hubei Province (No. 2020CFB517), the Natural Science Foundation of Guangdong Province (No. 2019A1515110350), and the National Natural Science Foundation of China (No. 51908436).

Institutional Review Board Statement: Not applicable.

Informed Consent Statement: Not applicable.

Data Availability Statement: All the data generated during this study are included in this article.

Acknowledgments: The authors are grateful for the research collaboration.

Conflicts of Interest: The authors declare no conflict of interest.

\section{References}

1. Gogoi, A.; Biswas, S.; Bora, J.; Bhattacharya, S.S.; Kumar, M. Effect of vermicomposting on copper and zinc removal in activated sludge with special emphasis on temporal variation. Ecohydrol. Hydrobiol. 2015, 15, 101-107. [CrossRef]

2. Gräfe, M.; Nachtegaal, M.; Sparks, D.L. Formation of Metal-Arsenate Precipitates at the Goethite-Water Interface. Environ. Sci. Technol. 2004, 38, 6561-6570. [CrossRef] [PubMed]

3. Yan, L.; Wang, W.; Li, X.; Duan, J.; Jing, C. Evaluating adsorption media for simultaneous removal of arsenate and cadmium from metallurgical wastewater. J. Environ. Chem. Eng. 2016, 4, 2795-2801. [CrossRef]

4. Yoon, K.; Cho, D.-W.; Tsang, D.; Bolan, N.; Rinklebe, J.; Song, H. Fabrication of engineered biochar from paper mill sludge and its application into removal of arsenic and cadmium in acidic water. Bioresour. Technol. 2017, 246, 69-75. [CrossRef] [PubMed]

5. Jiang, W.; Lv, J.; Luo, L.; Yang, K.; Lin, Y.; Hu, F.; Zhang, J.; Zhang, S. Arsenate and cadmium co-adsorption and co-precipitation on goethite. J. Hazard. Mater. 2013, 262, 55-63. [CrossRef] [PubMed]

6. Nath, S.G.; Debsarkar, A.; Dutta, A. Technology alternatives for decontamination of arsenic-rich groundwater-A critical review. Environ. Technol. Innov. 2018, 13, 277-303. [CrossRef]

7. Nishijo, M.; Nakagawa, H.; Suwazono, Y.; Nogawa, K.; Kido, T. Causes of death in patients with Itai-itai disease suffering from severe chronic cadmium poisoning: A nested case-control analysis of a follow-up study in Japan. BMJ Open 2017, 7, e015694. [CrossRef]

8. Sahmoune, M.N. The role of biosorbents in the removal of arsenic from water. Chem. Eng. Technol. 2016, 39, 1617-1628. [CrossRef]

9. Ghosh, D.; Saha, R.; Ghosh, A.; Nandi, R.; Saha, B. A review on toxic cadmium biosorption from contaminated wastewater. Desalination Water Treat. 2013, 53, 413-420. [CrossRef]

10. Du, L.; Yu, R.; Wang, H.-y.; LU Yun; Zheng, L. T. Pollution and toxicity of cadmium: A review of recent studies. J. Environ. Health 2013, 30, 167-174. [CrossRef]

11. Cheng, S.Y.; Show, P.-L.; Lau, B.F.; Chang, J.-S.; Ling, T.C. New Prospects for Modified Algae in Heavy Metal Adsorption. Trends Biotechnol. 2019, 37, 1255-1268. [CrossRef] 
12. Liao, Q.; Tu, G.; Yang, Z.; Wang, H.; He, L.; Tang, J.; Yang, W. Simultaneous adsorption of As(III), Cd(II) and Pb(II) by hybrid bionanocomposites of nano hydroxy ferric phosphate and hydroxy ferric sulfate particles coating on Aspergillus niger. Chemosphere 2019, 223, 551-559. [CrossRef]

13. He, J.; Chen, J.P. A comprehensive review on biosorption of heavy metals by algal biomass: Materials, performances, chemistry, and modeling simulation tools. Bioresour. Technol. 2014, 160, 67-78. [CrossRef] [PubMed]

14. Lebron, Y.; Moreira, V.; Santos, L. Studies on dye biosorption enhancement by chemically modified Fucus vesiculosus, Spirulina maxima and Chlorella pyrenoidosa algae. J. Clean. Prod. 2019, 240, 118197. [CrossRef]

15. Pereira, L.; Alves, M. Dyes-Environmental Impact and Remediation. In Environmental Protection Strategies for Sustainable Development; Malik, A., Grohmann, E., Eds.; Springer: Dordrecht, The Netherlands, 2012; pp. 111-162.

16. Lebron, Y.; Moreira, V.; Santos, L.; Jacob, R. Remediation of methylene blue from aqueous solution by Chlorella pyrenoidosa and Spirulina maxima biosorption: Equilibrium, kinetics, thermodynamics and optimization studies. J. Environ. Chem. Eng. 2018, 6, 6680-6690. [CrossRef]

17. Huq, E.; Fahad, S.; Shao, Z.; Sarven, M.S.; Khan, I.A.; Alam, M.; Saeed, M.; Ullah, H.; Adnan, M.; Saud, S.; et al. Arsenic in a groundwater environment in Bangladesh: Occurrence and mobilization. J. Environ. Manag. 2020, 262, 110318. [CrossRef]

18. Kousha, M.; Daneshvar, E.; Sohrabi, M.S.; Jokar, M.; Bhatnagar, A. Adsorption of acid orange II dye by raw and chemically modified brown macroalga Stoechospermum marginatum. Chem. Eng. J. 2012, 192, 67-76. [CrossRef]

19. Daneshvar, E.; Vazirzadeh, A.; Niazi, A.; Sillanpää, M.; Bhatnagar, A. A comparative study of methylene blue biosorption using different modified brown, red and green macroalgae-Effect of pretreatment. Chem. Eng. J. 2017, 307, 435-446. [CrossRef]

20. Feng, N.; Guo, X.; Liang, S.; Zhu, Y.; Liu, J. Biosorption of heavy metals from aqueous solutions by chemically modified orange peel. J. Hazard. Mater. 2011, 185, 49-54. [CrossRef] [PubMed]

21. García-Rosales, G.; Olguín, M.T.; Colin-Cruz, A.; Romero-Guzmán, E.T. Effect of the pH and temperature on the biosorption of lead(II) and cadmium(II) by sodium-modified stalk sponge of Zea mays. Environ. Sci. Pollut. Res. 2011, 19, 177-185. [CrossRef]

22. Wassie, A.B.; Srivastava, V.C. Chemical treatment of teff straw by sodium hydroxide, phosphoric acid and zinc chloride: Adsorptive removal of chromium. Int. J. Environ. Sci. Technol. 2016, 13, 2415-2426. [CrossRef]

23. Guo, X.; Yang, Z.; Dong, H.; Guan, X.; Ren, Q.; Lv, X.; Jin, X. Simple combination of oxidants with zero-valent-iron (ZVI) achieved very rapid and highly efficient removal of heavy metals from water. Water Res. 2015, 88, 671-680. [CrossRef]

24. Bulgariu, L.; Bulgariu, D. Enhancing Biosorption Characteristics of Marine Green Algae (Ulva lactuca) for Heavy Metals Removal by Alkaline Treatment. J. Bioprocess. Biotech. 2014, 4, 1-8. [CrossRef]

25. Yu, Q.; Matheickal, J.T.; Yin, P.; Kaewsarn, P. Heavy metal uptake capacities of common marine macro algal biomass. Water Res. 1999, 33, 1534-1537. [CrossRef]

26. Teodoro, F.S.; Ramos, S.N.D.C.; Elias, M.M.C.; Mageste, A.B.; Ferreira, G.M.D.; Da Silva, L.H.M.; Gil, L.F.; Gurgel, L.V.A. Synthesis and application of a new carboxylated cellulose derivative. Part I: Removal of $\mathrm{Co}^{2+}, \mathrm{Cu}^{2+}$ and $\mathrm{Ni}^{2+}$ from monocomponent spiked aqueous solution. J. Colloid Interface Sci. 2016, 483, 185-200. [CrossRef]

27. Moreira, V.; Lebron, Y.; Freire, S.; Santos, L.; Palladino, F.; Jacob, R. Biosorption of copper ions from aqueous solution using Chlorella pyrenoidosa: Optimization, equilibrium and kinetics studies. Microchem. J. 2018, 145, 119-129. [CrossRef]

28. Asere, T.G.; Stevens, C.V.; Du Laing, G. Use of (modified) natural adsorbents for arsenic remediation: A review. Sci. Total. Environ. 2019, 676, 706-720. [CrossRef]

29. Choi, H.-J.; Lee, S.-M. Heavy metal removal from acid mine drainage by calcined eggshell and microalgae hybrid system. Environ. Sci. Pollut. Res. 2015, 22, 13404-13411. [CrossRef] [PubMed]

30. Dhar, R.; Zheng, Y.; Rubenstone, J.; van Geen, A. A rapid colorimetric method for measuring arsenic concentrations in groundwater. Anal. Chim. Acta 2004, 526, 203-209. [CrossRef]

31. Kataria, N.; Garg, V. Green synthesis of $\mathrm{Fe}_{3} \mathrm{O}_{4}$ nanoparticles loaded sawdust carbon for cadmium (II) removal from water: Regeneration and mechanism. Chemosphere 2018, 208, 818-828. [CrossRef]

32. Lee, J.S.; Nriagu, J.O. Stability constants for metal arsenates. Environ. Chem. 2007, 4, 123-133. [CrossRef]

33. Sun, X.; Huang, H.; Zhu, Y.; Du, Y.; Yao, L.; Jiang, X.; Gao, P. Adsorption of $\mathrm{Pb}^{2+}$ and $\mathrm{Cd}^{2+}$ onto Spirulina platensis harvested by polyacrylamide in single and binary solution systems. Colloids Surf. A Physicochem. Eng. Asp. 2019, 583, 123926. [CrossRef]

34. Anwar, J.; Shafique, U.; Zaman, W.U.; Salman, M.; Dar, A.; Anwar, S. Removal of Pb(II) and Cd(II) from water by adsorption on peels of banana. Bioresour. Technol. 2010, 101, 1752-1755. [CrossRef]

35. Gupta, V.K.; Rastogi, A.; Nayak, A. Biosorption of nickel onto treated alga (Oedogonium hatei): Application of isotherm and kinetic models. J. Colloid Interface Sci. 2010, 342, 533-539. [CrossRef] [PubMed]

36. Vatutsina, O.; Soldatov, V.; Sokolova, V.; Johann, J.; Bissen, M.; Weissenbacher, A. A new hybrid (polymer/inorganic) fibrous sorbent for arsenic removal from drinking water. React. Funct. Polym. 2007, 67, 184-201. [CrossRef]

37. Batzias, F.; Sidiras, D. Simulation of methylene blue adsorption by salts-treated beech sawdust in batch and fixed-bed systems. J. Hazard. Mater. 2007, 149, 8-17. [CrossRef] [PubMed]

38. Ozdes, D.; Duran, C.; Senturk, H.B. Adsorptive removal of $\mathrm{Cd}(\mathrm{II})$ and $\mathrm{Pb}(\mathrm{II})$ ions from aqueous solutions by using Turkish illitic clay. J. Environ. Manag. 2011, 92, 3082-3090. [CrossRef]

39. Paulino, A.T.; Belfiore, L.A.; Kubota, L.T.; Muniz, E.; Almeida, V.C.; Tambourgi, E.B. Effect of magnetite on the adsorption behavior of $\mathrm{Pb}(\mathrm{II}), \mathrm{Cd}(\mathrm{II})$, and $\mathrm{Cu}(\mathrm{II})$ in chitosan-based hydrogels. Desalination 2011, 275, 187-196. [CrossRef] 
40. Segovia-Sandoval, S.J.; Ocampo-Pérez, R.; Berber-Mendoza, M.S.; Leyva-Ramos, R.; Jacobo-Azuara, A.; Medellín-Castillo, N.A. Walnut shell treated with citric acid and its application as biosorbent in the removal of $\mathrm{Zn}(\mathrm{II})$. J. Water Process. Eng. 2018, 25, 45-53. [CrossRef]

41. Sheng, P.X.; Ting, Y.-P.; Chen, J.; Hong, L. Sorption of lead, copper, cadmium, zinc, and nickel by marine algal biomass: Characterization of biosorptive capacity and investigation of mechanisms. J. Colloid Interface Sci. 2004, 275, 131-141. [CrossRef]

42. Gupta, V.; Rastogi, A. Equilibrium and kinetic modelling of cadmium(II) biosorption by nonliving algal biomass Oedogonium sp. from aqueous phase. J. Hazard. Mater. 2008, 153, 759-766. [CrossRef] [PubMed] 